\title{
Shining a Light on a Hidden Figure: Dorothy Hoover
}

\section{Lily Khadjavi, Tanya Moore, Kimberly Weems, and Ulrica Wilson}

It requires gumption to dream of a life path that is different from what is presented as possible. Too often when we speak of women in mathematics, we focus on the data highlighting underrepresentation and the obstacles they face, rather than acknowledging the contributions women have made to the field of mathematics and the courage their participation often required. Learning about the contributions of role models can go a long way to combat isolation and foster a sense of belonging within the challenging field of mathematics.

The Infinite Possibilities Conference (IPC) was created, in part, to highlight the role women of color have had in mathematics because their personal and professional journeys are inspirational and instructive and their history is powerful. IPC aims to inspire, support, and empower underrepresented minority women with a two- to threeday conference held biennially. Over the years, keynote speakers and honorees have included trailblazers such as Evelyn Boyd Granville, one of the first African American women to receive a PhD in mathematics; Freda Porter, one of the few Native American women with a PhD in applied mathematics, who now leads her own company; and Ruth Gonzalez, the first Latina to earn a doctorate in applied

Lily Khadjavi is an associate professor in the Department of Mathematics at Loyola Marymount University. Her email address is 1 khadjavi@1mu. edu.

Tanya Moore is founder of and partner at Intersecting Lines. Her email address is math@intersecting 7 ines.us.

Kimberly Weems is an associate professor of mathematics at NC Central University. Her email address is ksweems@nccu.edu.

Ulrica Wilson is an associate professor of mathematics at Morehouse College. Her email address is uwi 1 son@morehouse.edu.

Communicated by Notices Associate Editor Della Dumbaugh.

For permission to reprint this article, please contact: reprint-permission @ams.org.

DOI: https://dx.doi.org/10.1090/noti2046 mathematics. ${ }^{1}$ These groundbreakers and the stories of their journeys have existed all along, but if our historiographies fail to illuminate them, they remain unknown in our collective memory, effectively hidden.

Little did the IPC organizers know, but a story about African American female mathematicians would soon go mainstream. Margot Lee Shetterly presents a detailed picture of some of these women in her bestselling book, Hidden Figures: The American Dream and the Untold Story of the Black Women Mathematicians Who Helped Win the Space Race [14]. Through the lively portrayal in the movie, we now have a nascent awareness of this intersection of mathematics and the struggle for civil rights. Rich in historical detail, the text gives us a deep look at the stories of four women out of a larger group of African American women at NASA who worked as "human computers" and whose lives and work Shetterly revealed through her research. It is fair to say that the early history of women mathematicians at NASA was essentially unknown until the book was released.

Women contributed not only to the dramatic computations of the space race but to the field of aeronautics itself. In an effort to bring these accomplishments to light at the 2017 Joint Math Meetings, IPC had a special opportunity to coordinate a Hidden Figures-themed panel in partnership with AWM, EDGE, and NAM and with support from the AMS. The panel featured extended remarks by Shetterly, reminiscences and perspectives from former NASA "computer" Christine Darden (who was featured in Shetterly's book), and, at the suggestion of Ms. Shetterly, an overview of the life and work of Dorothy Hoover, presented by Ulrica Wilson of Morehouse College. Turnout for the panel

\footnotetext{
${ }^{1}$ See "The Infinite Possibilities Conference: Creating Moments of Belonging for Underrepresented Minority Women in Mathematics" in the forthcoming volume on Mathematical Communities edited by Della Dumbaugh and Deanna Haunsperger for more about this conference.
} 
overwhelmed the room; at the last moment, an adjoining room was opened to increase the capacity for the audience, and even then, there was standing room only. In fact, in his Retiring Presidential Address outgoing MAA President Francis Su made reference to the wonderful reception for this special panel presentation, "The Mathematics and Mathematicians Behind Hidden Figures."

The story of Dorothy Hoover has stayed with us, and in honor of Women's History Month we take a moment to shine a light on her life.

\section{Early Education and Career}

Dorothy Hoover was an African American whose life was noteworthy for her contributions to mathematics and aeronautics during a time of significant barriers for women and minorities in the United States. The granddaughter of slaves, Dorothy Estheryne McFadden was born July 1, 1918 to William Matthew McFadden and Elizabeth Wilburn McFadden in Hope, Arkansas. She earned a bachelor's degree in mathematics from Arkansas AM\&N College (now the University of Arkansas at Pine Bluff) in 1938. Her college was one of sixty-five Historically Black Colleges and Universities that participated in the Federal Engineering, Science, Management and War Training (ESMWT) programs, and Hoover was one of only two mathematics majors in her class $[11,13,14]$.

To put Hoover's early life in context, she graduated from college towards the end of the Great Depression, and her life spanned years embedded in the era of Jim Crow, a time of legalized racial segregation in the South. Two years after her graduation, only 3.8 percent of all women over twenty-five years of age in the US had completed four years of college or more (it was 1.2 percent for African American women) [18]. The 1940s and 1950s marked a time of educational and economic contradictions for African Americans in the United States. In 1943, Euphemia Lofton Haynes made history at Catholic University when she became the first African American woman to earn a PhD in mathemat-

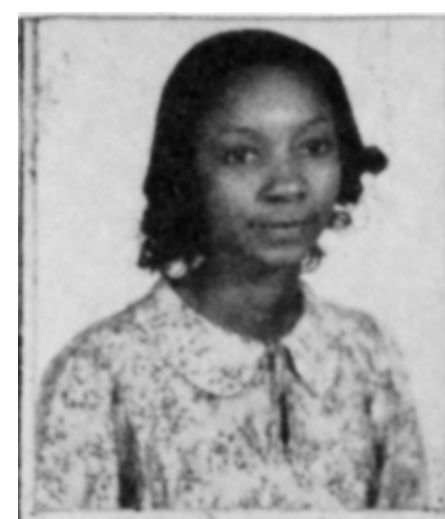

Dorothy McFadden, 1938. The Lion Yearbook, University of Arkansas at Pine Bluff (formerly Arkansas AM\&N College). ics at a time when many institutions of higher education remained closed altogether to women. (See [8] for more on Haynes's life and the time period.) The landmark ruling of Brown v. Board of Education, impacting public grade schools and high schools, didn't take place until 1954; even then a long period of resistance to desegregation continued. It was a chapter of remarkable achievements and "firsts," yet one in which segregation and societal norms explicitly limited educational and economic opportunities for women and African Americans.

After college, Hoover taught in schools of the rural South $[6,11]$. She then advanced her education, completing her master of science degree in mathematics at Atlanta University (now Clark Atlanta University), the first graduate school established for African Americans. Her 1943 MS thesis, "Some Projectile Transformations and Their Applications," serves as a prelude to her future work in aeronautics [2]. Later that year, she was hired as a P-1 mathematician at the National Advisory Committee for Aeronautics (NACA) Langley Research Center (now NASA) where she joined other black women mathematicians such as Dorothy Vaughan, who had been hired following President Franklin Roosevelt's executive order to desegregate the defense industry and whose story is highlighted in Shetterly's book.

While at Langley, Hoover's career flourished. She became a shift supervisor of the West Computing Unit comprised of African American women mathematicians ("human computers"). Engineers from the Stability Analysis Division, led by renowned aeronautical engineer Robert T. Jones, modeled aerodynamic performance, and the "computers" were responsible for numerical calculations [14]. At Jones's request, Hoover began to collaborate with him, and she now had the opportunity and access to include her own ideas about using swept-back wings on high-speed aircraft. In 1951, she was promoted to aeronautical research scientist (GS-9) and coauthored two NACA technical reports. In these reports, she and Frank Malvestuto derived approximations related to lift and pitch for thin swept-back, tapered wings with streamwise tips and applied the results to a range of supersonic speeds. Described by Shetterly as "exceptionally fluent in abstract mathematical concepts... with an aptitude for complex math so strong that it exceeded the ability of many of the engineers at the lab," Hoover made joint contributions on the aerodynamics of swept-back, tapered wings which became the aircraft industry standard $[9,10,14]$.

\section{Additional Education and Mid-Career Moves}

Hoover worked at Langley for almost ten years before taking a break from the workforce to further her education. In 1952, Hoover resigned from Langley and returned to Arkansas. She earned a master's degree in physics from the University of Arkansas in 1954, and her thesis, "Estimates of Error in Numerical Integration," was published in the Journal of the Arkansas Academy of Science [5]. ${ }^{2}$ Here she established a difference formula to get upper bounds for the error in the trapezoidal rule and Simpson's rule that do not depend on obtaining derivatives of the integrand. As

\footnotetext{
${ }^{2}$ This journal was previously called the Proceedings of the Arkansas Academy of Science.
} 
one of only fifteen African American graduate students at the University of Arkansas ${ }^{3}$ during that time [16], Hoover is believed to be the first African American woman to earn a physics degree from the university and the first African American woman to earn two technical master's degrees [11,13].

Later in 1954, Hoover was awarded a John Hay Whitney Foundation Opportunity Fellowship, a competitive grant aimed at candidates with "evidence of special ability" and "exceptional promise" who have "not had full opportunity to develop his [sic] talents because of arbitrary barriers, such as racial or cultural background or region of residence" [7]. She entered the PhD program in mathematics at the University of Michigan, serving as a teaching fellow and as an instructor of "school algebra" and trigonometry [19]. At this time, only three African American women had earned PhDs in mathematics-Haynes (Catholic University, 1943), Granville (Yale, 1949), and Marjorie Lee Browne (Michigan, 1950)-and over one-third of the PhDs in mathematics earned by African Americans had been awarded by the University of Michigan [20]. ${ }^{4}$ Hoover completed the typical coursework during her first three semesters, taking classes in algebra, analysis, geometry, and topology. She also passed language exams in French and German. For reasons unknown, however, she resigned as a teaching fellow in 1956 and subsequently left the PhD program before completing her preliminary (qualifying) examinations.

Hoover returned to the Washington, DC area, where she served in a variety of government positions. From 1956 to 1959 , she was a mathematician at the Joint Numerical Weather Prediction Unit, a collaborative effort between the US Weather Bureau, the Army, and the Navy, where meteorologists, mathematicians, and other scientists used atmospheric data to make real-time weather forecasts, a significant achievement at that time [3]. For over a year on a grid covering more than 24 billion acres of the earth's surface, this Unit worked on solving a formulation of the balance equation

$$
f\left(\frac{\partial^{2} \psi}{\partial x^{2}}+\frac{\partial^{2} \psi}{\partial y^{2}}\right)-2\left(\left(\frac{\partial^{2} \psi}{\partial x \partial y}\right)^{2}-\frac{\partial^{2} \psi}{\partial x^{2}} \frac{\partial^{2} \psi}{\partial y^{2}}\right)=\nabla^{2} \phi,
$$

\footnotetext{
$\overline{{ }^{3} \text { African American undergraduate students were not admitted to the Uni- }}$ versity of Arkansas until 1955.

${ }^{4}$ There were still significant barriers for African American mathematicians at prominent universities. William Waldron Schieffelin Claytor, who was the third African American in the country to earn a PhD and whose work appeared in the Annals of Mathematics, was a postdoc at the University of Michigan in the 1930s but was thwarted when seeking faculty positions at Michigan and elsewhere. He first taught at West Virginia State College, an HBCU, and indeed Katherine Johnson, now famous for her work at NASA and featured in Shetterly's text, was one of his students there [12].
}

where $f$ is the Coriolis parameter, $\psi$ is the stream function, and $\Phi$ is the pressure field. An October 1957 technical report published in the Monthly Weather Review outlines two methods this Unit used to numerically approximate a solution to the balance equation and acknowledges Hoover and four other mathematicians for their contributions to this work [15].

In 1959, she returned to space research, working at NASA Goddard and earning a promotion to the senior rank of GS-13 mathematician in 1962. Given that the highest General Schedule (GS) level for federal employees is 15, this was an impressive accomplishment, particularly for an African American woman in the 1960s. During her time at Goddard, she coauthored the chapter "Nonseparable Theory of Electron-Hydrogen Scattering," which appeared in the 1963 book titled Methods in Computational Physics [17]. In this chapter, the authors presented a PDE with suitable boundary conditions used to model the scattering of electrons from atomic hydrogen. Analytical and numerical results along with FORTRAN code were given.

\section{A Scholarly Life Beyond Mathematics}

A gifted scholar, Hoover was a member of Pi Mu Epsilon as well as the physics honor society Sigma Pi Sigma. In addition, she gave back to her community through her involvement with the NAACP and as an active member of her church, where she participated in outreach ministries $[6,13]$.

While continuing her mathematics research in Goddard's Theoretical Division, Hoover's faith led her to begin writing a book, A Layman Looks with Love at Her Church, that chronicles the history of the African Methodist Episcopal (AME) Church of the US [6]. This book provided an opportunity for her to reflect on her childhood in Arkansas and the influence of her churchgoing parents. The attention to detail as well as the careful study that made her a successful mathematician revealed itself in this work. In the preface, dated November 22, 1966, Hoover wrote the following:

When I began to gather material and delve into it, I thought how rich a heritage!...It was total involvement....Lunch hours, leisure, week-ends [sic] would be full for many months; but, as I lost myself in "a total involvement," I again knew a peace of mind I had lost and longed for.

...what I have done was not as a paid full-time writer, but in response to the dictates of my own will in what time I had left from my full-time job at the Goddard Space Flight Center. I only ask that my work be accepted in the spirit in which it was done. 
Hoover's book was published in 1970, two years after she began working as an operations research analyst at the Defense Communications Agency (now the Defense Information Systems Agency), where she also served as a program officer and received a twenty-year federal service award [1].

\section{Reflections}

Hoover died February 7, 2000 in Washington, DC. She was predeceased by her children: a daughter Viola Clementine from her first marriage to Sylvanus Bowe Clarke and a son Ricardo Allen with her second husband Richard Allen Hoover [13].

The more we reached into her story, the more we realized that Hoover exemplifies courage, determination, and resiliency. She remains a role model. As the mathematics community seeks ways to broaden participation from underrepresented groups, it is important to highlight the outstanding contributions of those who excelled despite inequities. What if every time a student learned about the trapezoid rule, they learned of Hoover and her paper?

We wonder about her experiences as a PhD student and why she left her program. Indeed, had she continued, Hoover likely would have become the fourth African American woman to earn a PhD in mathematics. Yet, we are aware that a sense of belonging in a doctoral mathematics program can be diminished in part by the reasons outlined by Herzig [4]: a lack of role models, the need to prove one's worth, conflicting demands of family and school obligations, and isolation. Though the details are different, our journey to do mathematics and engage in the community of mathematics is parallel to hers. We recognize her and identify with her being the "first," the "only one," or "one of few."

Like many of us, Hoover searched for balance. When asked to organize a new club at her church, she struggled with whether she could complete this task given her demanding career:

I am a civil servant, a full-time mathematician. I continue to debate how I could manage to... organize material, in the meager time I had, for the things I would want to do the way I would want to do them. [6]

She possessed a sense of possibility in the midst of legally and culturally sanctioned segregation and limited access to education and jobs. In honoring her life, we are reminded that our lives and contributions matter as well.

As Su noted in his moving plenary address, "I know our community wants to be just. To set things right. If you were at the Hidden Figures panel...you saw the turnout. There were so many people, we had to open a second room and even then, it was standing room only. So I know our community wants to do better." Recognizing and taking inspiration from this history is an integral part of our development as a mathematics community. So let's open another room-and even break down the walls-as we increase access and opportunities for participation.

ACKNOWLEDGMENTS. The authors wish to thank Margot Lee Shetterly for her recommendation to explore the life and mathematical contributions of Dorothy Hoover.

Appreciation is also extended to Sylvia Bozeman, Ami Radunskaya, Stephanie Pugh-Williams of the University of Arkansas at Pine Bluff Office of Alumni Affairs/Governmental Relations, and the staff of the University of Michigan Bentley Historical Library.

The authors are grateful to the reviewers for their helpful suggestions and comments that improved this article.

\section{References}

[1] All Around Town, Hope Star 69 (October 8, 1968), no. 304, 10, accessed November 16, 2016. https://www . newspapers.com/c1 ip/7473114/hope_star_hope _arkansasp10/

[2] G. W. Barksdale, Graduate Theses of Atlanta University, 1943-1947, Indices to Atlanta University Historical Theses and Dissertations, The Atlanta University Center Robert W. Woodruff Library, Atlanta, GA, 1948.

[3] K. Harper, L. W. Uccellini, E. Kalnay, K. Carey, and L. Morone, 50th Anniversary of Operational Numerical Weather Prediction, Bulletin of the American Meteorological Society 88 (May 2007), no. 5, 639-650, DOI 10.1175/BAMS -88-5-639

[4] A. H. Herzig, Women Belonging in the Social Worlds of Graduate Mathematics, The Mathematics Enthusiast 7 (2010), no. 2, 177-208. https://scholarworks.umt.edu/tme /vol7/iss2/2

[5] D. M. Hoover, Estimates of Error in Numerical Integration, Journal of the Arkansas Academy of Science 8 (1955), 204-207, accessed June 29, 2018. https://scholarworks . uark. edu/jaas/vo18/iss1/23/

[6] D. E. Hoover, A Layman Looks with Love at Her Church, Dorrance and Company: Philadelphia, 1970.

[7] Information Sheet about Opportunity Fellowships, John Hay Whitney Foundation, accessed August 29, 2019. https://texashistory.unt.edu/ark:/67531/metapth 250263/

[8] Susan E. Kelly, Carly Shinners, and Katherine Zoroufy, Euphemia Lofton Haynes: bringing education closer to the "goal of perfection", Notices Amer. Math. Soc. 64 (2017), no. 9, 995-1003, DOI 10.1090/noti1579 MR3699774

[9] F. S. Malvestuto and D. M. Hoover, Supersonic Lift and Pitching Moment of Thin Sweptback Tapered Wings Produced by Constant Vertical Acceleration: Subsonic Leading Edges and Supersonic Trailing Edges, NACA Technical (March 1951), no. 2315, Washington, DC: National Advisory Committee for Aeronautics, accessed June 29, 2018. https://mirlyn . 1 ib.umich.edu/Record/012862388/Home 


\section{HISTORY}

[10] F. S. Malvestuto and D. M. Hoover, Lift and Pitching Derivatives of Thin Sweptback Tapered Wings with Streamwise Tips and Subsonic Leading Edges at Supersonic Speeds, NACA Technical (February 1951), no. 2294, Langley Field, VA: National Advisory Committee for Aeronautics, Langley Aeronautical Lab, accessed June 29, 2018. https://digita1 . 1ibrary.unt.edu/ark:/67531/metadc55650/

[11] K. P. McKinney, Dorothy McFadden Hoover: No Longer a Hidden Figure, Only in Arkansas (February 16, 2019), accessed June 29, 2018. https://onlyinark.com/culture /dorothy-mcfadden-hoover-no-1onger-a-hidden -figure/

[12] Karen Hunger Parshall, Mathematics and the politics of race: the case of William Claytor (Ph.D., University of Pennsylvania, 1933), Amer. Math. Monthly 123 (2016), no. 3, 214-240, DOI 10.4169/amer.math.monthly.123.3.214 MR3482351

[13] R. D. Sallee, J. Russell, and E. Turner, Dorothy McFadden Hoover (1918-2000), Central Arkansas Library System Encyclopedia of Arkansas, 2018, accessed August 12, 2019. https://encyclopediaofarkansas.net/entries /dorothy-mcfadden-hoover-12344/

[14] M. L. Shetterly, Hidden Figures: The American Dream and the Untold Story of the Black Women Mathematicians Who Helped Win the Space Race, New York: William Morrow, 2016.

[15] F. G. Shuman, Numerical Methods in Weather Prediction: I. The Balance Equation, Monthly Weather Review, ed. J. E. Caskey, Jr., 85 (October 1957), no. 10, 329-332. https:// doi . orq/10 .1175/1520-0493(1957)085<0329: NMIWPI $>2.0 . \mathrm{CO} ; 2$

[16] R. B. Slater, The First Black Graduates of the Nation's 50 Flagship State Universities, The Journal of Blacks in Higher Education 13 (Autumn 1996), 72-85.

[17] A. Tempkin and D. E. Hoover, Nonseparable Theory of Electron-Hydrogen Scattering, in: B. Alder, S. Fernbach, and M. Rotenberg (eds.), Methods in Computational Physics: Advances in Research and Applications, Vol. 2: Quantum Mechanics, New York: Academic Press, 1963, 181-240, accessed August 23, 2019. https: //archive.org/detai1s /in.ernet.d7i.2015.140738/paqe/n13

[18] US Census Bureau, A Half-Century of Learning: Historical Statistics on Educational Attainment in the United States, 1940 to 2000, Report Number PHC-T-41, Washington, DC: US Government Printing Office, April 2006, accessed August 25, 2019. https: //www. census . gov/data /tables/2000/dec/phc-t-41.html

[19] University of Michigan Official Publication, Vol. 57, University of Michigan Libraries, 1955.

[20] S. Williams, Mathematicians of the African Diaspora, accessed August 12, 2019. www. math. butta lo.edu/mad/mad hist.htm 1 